\title{
Exo- and endoglucanase production by Curvularia affinis using bean (Phaseolus vulgaris L.) waste biomass
}

\author{
M. M. Alawlaqi ${ }^{*}$ and Asmaa A. Alharbi
}

\begin{abstract}
Background: In many countries, agricultural residues are generated in large quantities, and most of these are underutilized and considered waste, especially in developing countries.

Result: In this study, Curvularia affinis was isolated from the leaves of Phaseolus vulgaris L. beans and identified using $18 \mathrm{~S}$ rRNA sequencing. C. affinis was tested for exo- and endoglucanase production using biomass of bean waste compared with the use of microcrystalline cellulose (MCC) and carboxymethylcellulose (CMC) as its growth substrates. $C$. affinis was better able to produce exo- and endoglucanase enzymes on bean waste biomass than on MCC and CMC. The highest activities of exo- and endoglucanase were detected with substrate concentrations $2 \%$ using MCC or CMC and with $4 \%$ using bean waste. The optimum incubation period for enzymes activity was 6 days with MCC or CMC (activity was 5.90 and $2.99 \mathrm{U} / \mathrm{g}$ of exoglucanase and endoglucanase, respectively) and 8 days with bean waste where activity was $3.64 \mathrm{U} / \mathrm{g}$ and $0.92 \mathrm{U} / \mathrm{g}$ of exoglucanase and endoglucanase, respectively. Exo- and endoglucanase production showed the highest activity at pH 5-6. In process wherein surfactant (Tween 80) was used, the exoglucanase activity gradually increased from $5.92 \mathrm{U} / \mathrm{g}$ to $6.20 \mathrm{U} / \mathrm{g}$ and then decreased to $5.70 \mathrm{U} / \mathrm{g}$ at $0.50 \%$ compared with that using the MCC substrate. The exoglucanase activity gradually increased from $3.80 \mathrm{U} / \mathrm{g}$ at $0.0 \%$ to $4.12 \mathrm{U} / \mathrm{g}$ at $0.20 \%$ and then decreased to $3.01 \mathrm{U} / \mathrm{g}$ at $0.50 \%$ Tween 80 using bean waste. Pretreated bean biomass also yielded higher enzyme production than the non-pretreated biomass. Alkaline-pretreated biomass showed the highest enzyme production compared with acid-treated residues, followed by the $\mathrm{H}_{2} \mathrm{O}_{2}$-treated ones.

Conclusion: The study concluded that $C$. affinis produce exo- and endoglucanase enzymes using cheap and abundant biomass of beans. Moreover, optimization of enzymes indicated that pretreatment of biomass bean biomass is a good choice process for enhanced enzymes productivity.
\end{abstract}

Keywords: Exoglucanase, Endoglucanase, Curvularia affinis, Bean, Waste biomass

\section{Introduction}

The global food, agricultural, and forestry industries produce great amounts of wastes annually, which lead to several environmental problems (Rodríguez-Couto 2008). Agricultural residues represent substantial raw materials that can be used to produce value-added products. The major constituents of agricultural residues include

*Correspondence: mohamedalawlaqi@hotmail.com Biology Department, Faculty of Science, Jazan University, Jazan, Saudi Arabia cellulose (35\%-50\%), hemicellulose $(20 \%-35 \%)$, and lignin $(15 \%-25 \%)$ as well as a number of other components comprising the residues (Wyman 1994; Keegstra 2010). Cellulose consists mainly of long polymers of 1-4, linked glucose units (Somerville 2006). Current academic and applied studies are devoting increasing efforts to minimizing the quantity of these wastes by finding alternative uses. Their composition rich in sugars, which is due to their organic nature, is easily assimilated by microorganisms (Rodríguez-couto 2008; Abdel-Ghany 
et al. 2018a). Diverse waste bioresources are available in our planet for conversion into bioproducts (Verma et al. 2011) such as pea peel (Verma et al. 2011) sugarcane bagasse (Rocha et al. 2014), barley straw (Abdelghany et al. 2018a). Bean (Phaseolus vulgaris L.) is the most important food legume worldwide, and its suitability as fungus immobilization carrier for solid-state fermentation has been assessed in a past study (Orzua et al. 2009). Tunali et al. (2007) reported that the waste biomass of bean (P. vulgaris L.) has a potential to be utilized as an alternative for the removal of acid red 57 dye from aqueous solutions because of its availability, low cost, and reasonable biosorption capacity.

Cellulase enzymes have been applied in a number of industrial processes, including textile, paper; and pulp manufacturing; food and animal feed production; biofuel and chemical processes; waste management; pharmaceutical processes; and pollution control (Bhat 2000; Acharya et al. 2008; Makky and Abdel-Ghany 2009; Mohajershojaei et al. 2013; Rocha et al. 2014). Cellulases consist of three major enzyme components, which are endo- $\beta$-(1-4)-D-glucanase or carboxymethylcellulases (CMCases), exo- $\beta$-(1-4)-D-glucanase, and $\beta$-glucosidase that work synergically in complex cellulose degradation (Saha 2004 and Kim et al. 2008). $\beta$-Glucosidases, also named $\beta$-D-glucosideglucohydrolase, EC 3.2.1.21), catalyze the hydrolysis of $\beta$-glucosidic linkages, such as alkyl and aryl $\beta$-glucosides, $\beta$-linked oligosaccharides, and several oligosaccharides with the release of glucose (Béguin 1990; Lin et al. 1999). $\beta$-Glucosidases are a prominent class of enzymes that catalyze cellulose degradation acting synergistically with cellobiohydrolase and endoglucanase (Henrissat et al. 1985).

Most microbial cellulases are inducible enzymes; similar to other extracellular enzymes, they are secreted when microorganisms are grown on cellulose or cellulosic components present in raw materials (Jecu 2000). A number of fungi and plant pathogens play an important role in various industrial applications (Abdel-Razek et al. 2009; Abdel-Ghany 2013; Abdelghany et al. 2014; Abdel-Ghany and Masmali 2016; Abdelghany et al. 2018b; Abdel-Ghany et al. 2019) and can produce multiple groups of enzymes, called cellulases, which hydrolyze the $\beta$-1,4-D-glycosidic bonds within agricultural wastes (Moreira et al. 2005; Chen et al. 2018; AbdelGhany and Bakri 2019). Numerous studies reported that fungal cellulase production is regulated in response to carbon sources and metal ions (Mandels and Reese 1957; Chen et al. 2016 and 2018). Recently, Chen et al. (2018) found that $\mathrm{Mn}^{2+}$ induced cellulase production, and upregulated the cellulase genes in Trichoderma reesei through calcium channels and calcium signaling.
Curvularia is a species-rich genus of pathogens and saprobes associated with human, plant and animals worldwide (Madrid et al. 2014, Marin-Felix et al. 2017). Leaf blights, seed and root rot, seedling blights, grain discolouration have been recorded due to Curvularia species (Iftikhar et al. 2003). Numerous species of Curvularia, viz., C. eragrostidis, C. geniculata, C. intermedia, C. pallescens, C. verruculosa, C. lunata and C. penniseti are known to be pathogenic to crops and grasses in many countries of the world (Wilson 2000). C. affinis was recorded as phytopathogen (Huang et al. 2004; Sharma et al. 2012). Besides phytopathogenesis of Curvularia species, lignocellulolytic enzyme activities of $C$. affinis was detected on agricultural waste such as wheat bran (Anasontzis et al. 2017). Recently, the ability of Curvularia verruculosa to secrete hydrolytic enzymes viz., pectinase, xylanase, protease, cellulase and lipase was detected (Shirsath et al. 2018). The objectives of our study were to estimate the potential of opportunistic fungus $C$. affinis isolated from the leaves of $P$. vulgaris $\mathrm{L}$. beans to produce exo- and endoglucanase enzymes using bean waste biomass, and to determine the different environmental factors that affect its secretion.

\section{Materials and methods}

\section{Agricultural waste biomass used for C. affinis exo-} and endoglucanase production

The agricultural wastes used in this study were provided in the form of biomass comprising leaves and stems of $P$. vulgaris $\mathrm{L}$. beans. These were cultivated in Monufia Governorate fields $\left(30^{\circ} 31^{\prime} 12^{\prime \prime} \mathrm{N}, 30^{\circ} 59^{\prime} 24^{\prime \prime} \mathrm{E}\right)$ located in Egypt.

\section{Fungal isolate used for exo- and endoglucanase production}

For isolation of fungal pathogen, small pieces $\left(2-5 \mathrm{~mm}^{2}\right)$ of infected leaves of $P$. vulgaris $\mathrm{L}$. with rust and spot diseases (Fig. 1) were surface-sterilized with hydrogen peroxide $(50 \%)$ solution. The sterilized pieces were aseptically transferred to sterile Petri dishes containing potato dextrose agar (PDA) medium (dextrose $20 \mathrm{~g}$, potato starch $4 \mathrm{~g}$, agar $15 \mathrm{~g} / \mathrm{L}$ distilled water. A portion of mycelium growing on the PDA medium after 5 days was transferred to the PDA for purification, identification and storage for further examination. The morphological identification of $C$. affinis was conducted by observing the colony color, conidia shape, and colony growth using PDA. Molecular identification was then performed by $18 \mathrm{~S}$ rRNA sequencing. For DNA extraction, $0.2 \mathrm{~g}$ of fungal mycelia were collected and placed in liquid nitrogen for $10 \mathrm{~min}$, then 


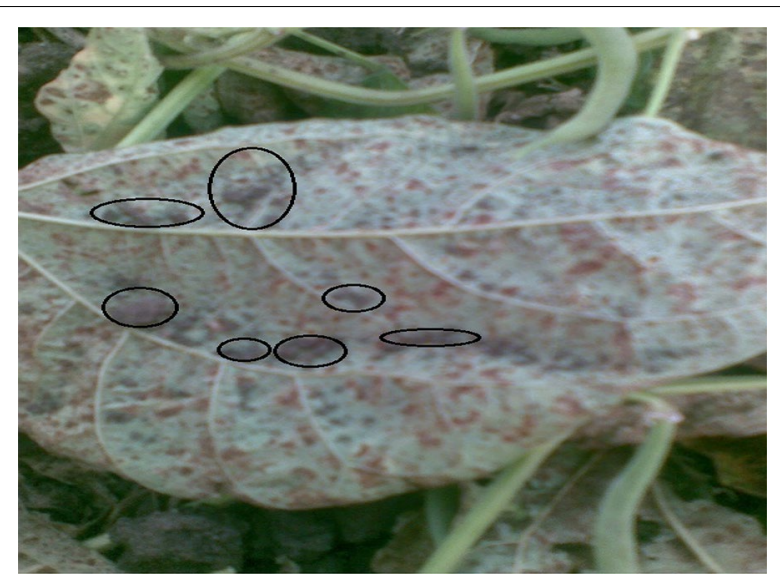

Fig. 1 Curvularia affinis spots inside black circle associated with rust spots (brown)

vigorously homogenized to extract its genomic DNA. DNA extract was mixed with $500 \mu \mathrm{L}$ of DNA extraction buffer (200 mM Tris-HCl, $240 \mathrm{mM} \mathrm{NaCl}, 25 \mathrm{mM}$ EDTA, and 1\% SDS (pH 8.0), then shaken for $5 \mathrm{~min}$ and then centrifuged for $5 \mathrm{~min}$ at 10,000 rpm. Next, the supernatant was mixed with an equal volume of phenol: chloroform $(1: 1 \mathrm{v} / \mathrm{v})$ for $30 \mathrm{~min}$ and again centrifuged for $5 \mathrm{~min}$ at $12,000 \mathrm{rpm}$, then the upper part was gently outgoing and mixed with an equal volume of $3 \mathrm{M}$ sodium acetate buffer ( $\mathrm{pH} 5.2)$ and 2 volumes of $96 \%$ ethanol for $1 \mathrm{~h}$ at $-20{ }^{\circ} \mathrm{C}$. The collected DNA after centrifugation, was washed with $70 \%$ ethanol, followed by drying until removal of the ethanol, and resuspended in $100 \mu \mathrm{L}$ of distilled water. PCR analysis was conducted according to Sambrook et al. (2001). Molecular Evolutionary Genetics Analysis software (Version 6; MEGA6) was used for the phylogenetic analyses (Tamura et al. 2013). DNA sequencing was performed by Macrogen Inc. (Seoul, South Korea). All intertranscribed spacer sequencing works were also completed by Macrogen on both strands of the submitted DNA fragments. The sequences were assembled, edited, and aligned using the DNA STAR SeqMan (DNASTAR Inc., Madison, Wisconsin USA) and the CLC sequence viewer. The C. affinis isolate was used for cellulase production assays.

\section{Exo- and endoglucanase production by $C$. affinis}

The submerged culture was used for the exo- and endoglucanase production by Curvularia affinis, using microcrystalline cellulose (MCC) and carboxymethylcellulose (CMC) as substrates and the agricultural waste of $P$. vulgaris $\mathrm{L}$. bean for both enzymes at different incubation periods (2, 3, 4, 5, 6, 7, 8 and 9 days), and at different substrate concentrations of $\mathrm{MCC}, \mathrm{CMC}$, and bean substrates ranging from $1 \%$ to $5 \%$.

Bean waste was washed in distilled water to remove any dust and then dried at $60{ }^{\circ} \mathrm{C}$ in an oven to obtain a constant weight. The dried waste was ground using a grinder (Molix, China) and sieved to select particle sizes of less than $0.001 \mathrm{~mm}$. Spore suspension of $C$. affinis $\left(5 \times 10^{6}\right.$ spores $/ \mathrm{ml}$ ) was inoculated in sterile Czapek Dox broth containing MCC $(2 \%)$ or CMC $(2 \%)$ or bean waste $(4 \%)$ instead of sucrose and then incubated in a rotary shaker at $120 \mathrm{rpm}$. After each incubation period, aliquots were centrifuged at 12,000 rpm to obtain the supernatant for the enzyme assay. The enzyme activity (unit) was measured as micromole sugar released per min. The exo- and endoglucanase activities were estimated using the MCC and CMC as substrates, respectively. The reaction mixtures contained $1 \mathrm{ml}$ of culture supernatant having enzyme with $10 \mathrm{mg}$ CMC or CMC suspended in $1 \mathrm{ml}$ of $0.05 \mathrm{M}$ sodium acetate buffer ( $\mathrm{pH}$ 5.0). The mixtures were incubated for $30 \mathrm{~min}$ at $50{ }^{\circ} \mathrm{C}$. For measuring the formed reducing sugar, $1 \mathrm{ml}$ of dinitrosalicylic acid was added to $3 \mathrm{ml}$ of the test sample, and the mixture was boiled in a water bath for $5 \mathrm{~min}$. The developed color was measured at a wavelength of $540 \mathrm{~nm}$ using a spectrophotometer (Jenway Model 6300, EU). The reduction of sugar concentration was achieved via a standard glucose concentration curve (Zaldivar et al. 2001).

\section{Effect of $\mathrm{pH}$ on exo- and endoglucanase production}

In order to determine optimal $\mathrm{pH}, C$. affinis was cultivated in a $250-\mathrm{ml}$ conical flask containing $50 \mathrm{ml}$ of optimized media with different $\mathrm{pH}$ ranging from 3 to 9 . The $\mathrm{pH}$ of the media was adjusted by using buffers, including citrate, citrate phosphate, and Tris buffers with $\mathrm{pH} 3-6$, 7 , and $8-9$, respectively.

\section{Effect of polysorbate 80 on exo- and endoglucanase production}

Polysorbate 80 (Tween 80) surfactant was added in concentrations of $0.1,0.2,0.3,0.4$, and $0.5 \mathrm{~mL} / \mathrm{g}$ of biomass. The same conditions for enzyme production (i.e., substrate concentration, incubation period of 8 days at $25{ }^{\circ} \mathrm{C}$ ) were used, as described in the previous experimental procedures.

\section{Pretreatment of bean substrate for exo- and endoglucanase production}

The sun-dried bean substrate was ground to acquire its powdered form and then soaked in $1 \mathrm{~N}_{\text {of }} \mathrm{H}_{2} \mathrm{SO}_{4}, \mathrm{NaOH}$, and $\mathrm{H}_{2} \mathrm{O}_{2}$ for the acid, alkali, and oxidative pretreatments, respectively, in the ratio of 1:10 (substrate: $1 \%$ solution)for $2 \mathrm{~h}$ at $25{ }^{\circ} \mathrm{C}$. This procedure was performed 
on the basis of a method described previously (Gharpuray et al. 1983; Singh and Bishnoi 2013) and with minimal modification. The treated biomass was filtered and washed repeatedly with distilled water to remove the solvents used for pretreatment and until the wash water became neutral. The resulting biomass was dried at $60{ }^{\circ} \mathrm{C}$ to a constant weight for enzyme production.

\section{Statistical data analyses}

The results are reported as mean \pm standard error SE of three independent replicates. Statistical analyses of data were carried out by computer using SPSS ver. 22.0 software.

\section{Results and discussion}

Isolation and identification of the $C$. affinis

from the infected $P$. vulgaris $\mathrm{L}$.

The identification of the $C$. affinis fungus was conducted morphologically (Fig. 2a-c), and the macroscopic examination of the isolated fungus on PDA indicated it to be wooly, white to gray at first. At growth maturation, the colony became black and appeared black on the reverse side of the agar plate. Identification was confirmed by molecular characterization, which was based on ITS rDNA. The $18 \mathrm{~S}$ rRNA sequence of the $C$. affinis isolate was searched on a database (Basic Local Alignment Search Tool) using multiple sequence alignment (Fig. 3) with MEGA6 software. From the alignment profile results, the $18 \mathrm{~S}$ ribosomal RNA gene amplicon of $C$. affinis strain 18 closely matched that of other $C$. affinis isolates (at $>89 \%$ ). This method of the molecular identification of fungi at the species level is primarily based on
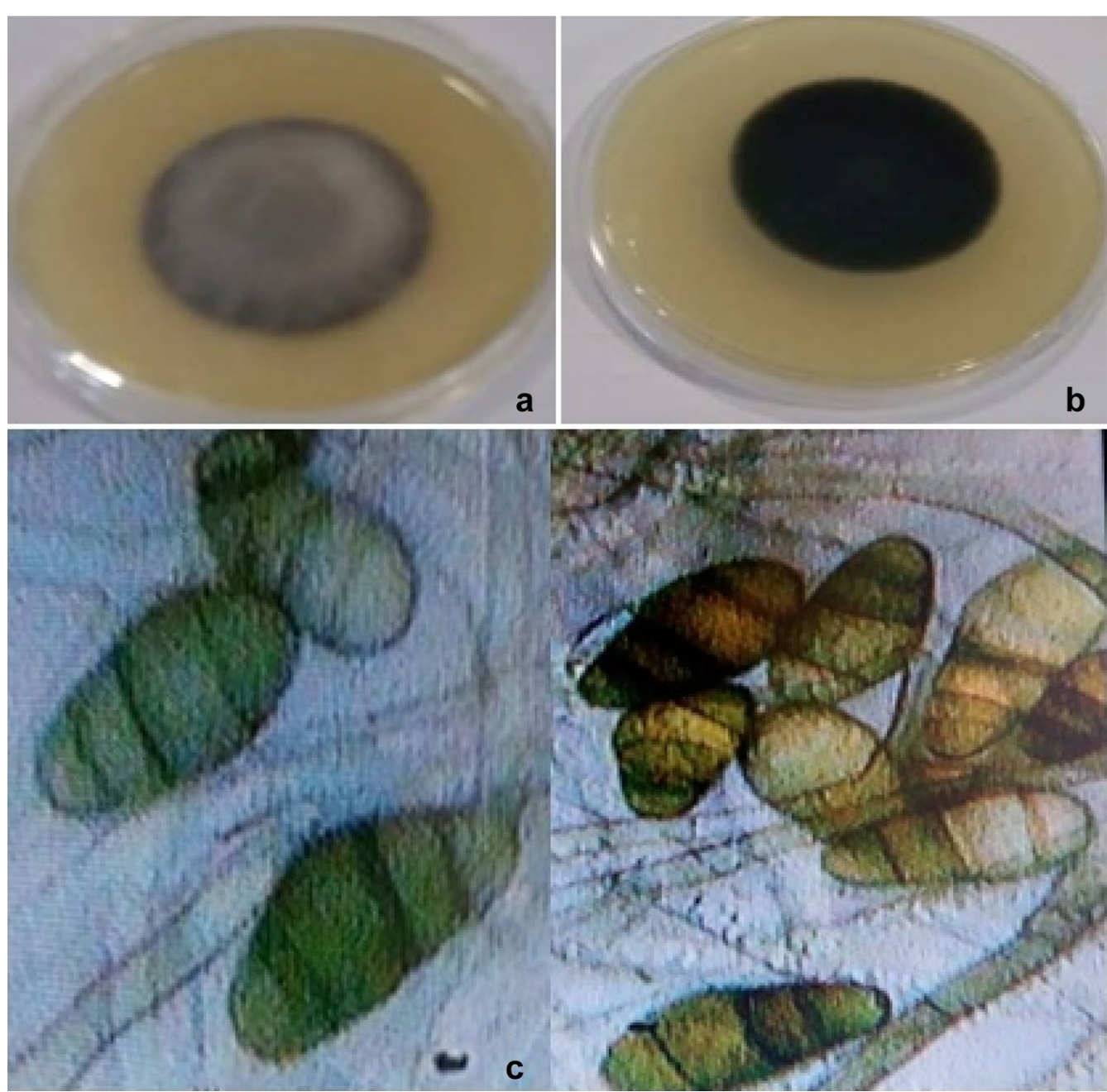

Fig. 2 Macroscopic (a colony color and $\mathbf{b}$ reverse side) and microscopic $\mathbf{c}$ diagnosis of C. affinis 


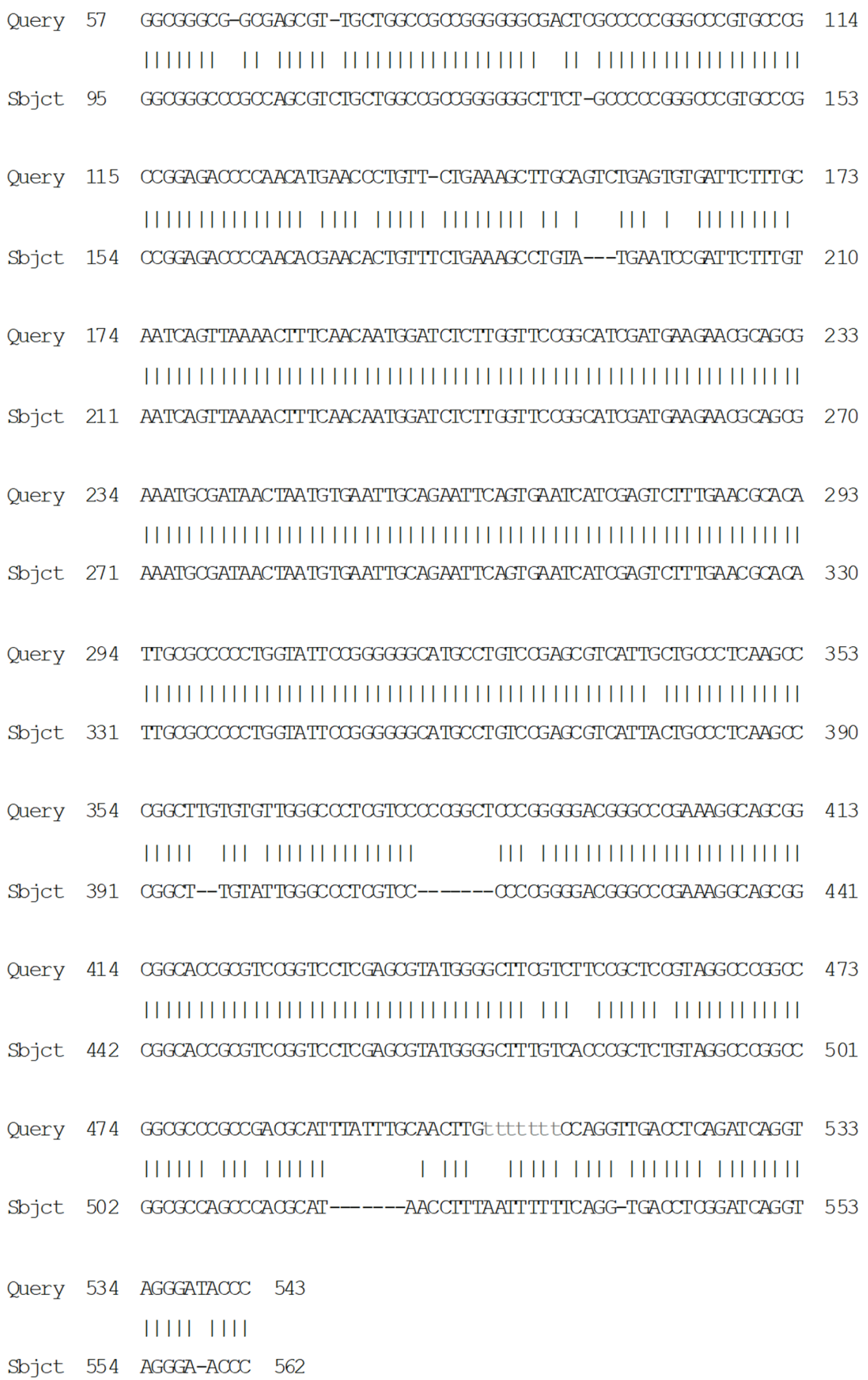

Fig. 3 Curvularia affinis strain 18185 ribosomal RNA gene and cluster analysis 


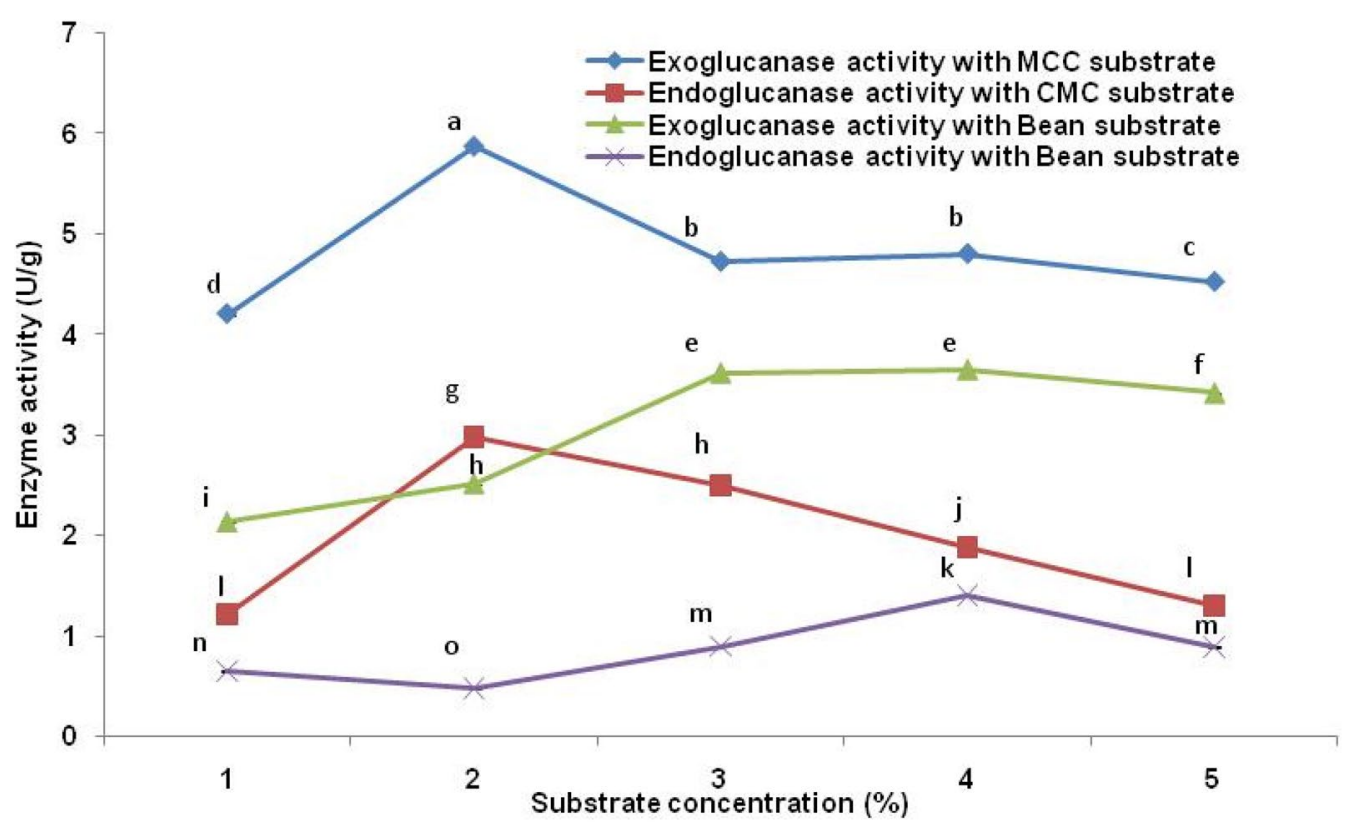

Fig. 4 Effect of different substrate concentrations (\%) on exoglucanase and endoglucanase activities using MCC, CMC and bean substrates

the variable nature of the ITS regions of DNA (Romanelli et al. 2010; Delgado-Serrano et al. 2016).

C. affinis was isolated as opportunistic fungus from the infected $P$. vulgaris L. with rust diseases (Fig. 1). Some Curvularia species from different parts of the world have been reported as plant pathogens that cause leaf blight, sheath rot, black kernel, sheath blight, leaf spot, and grain discoloration of rice (Kamaluddeen et al. 2013; Krishnan et al. 2014; Madhusree and Surekha 2017). Curvularia spp., including $C$. eragrostidis, $C$. geniculata, C. intermedia, C. inaequalis, C. lunata, C. pallescens, $C$. protuberata, and $C$. trifolii, affects many species of grasses worldwide (Smith et al. 1989). Weng et al. (1997) found that the most frequent disease of warm season grasses in southern China was caused by C. lunata. Meanwhile, C. affinis has been found on Festuca arundinacea (Huang et al. 2004). Solehudin et al. (2012) also reported that C. affinis widely attacks oil palm leaves (Elaeis guineensis Jacq.).

\section{Exo- and endoglucanase production from $C$. affinis}

The current result showed that the C. affinis strain exhibited exo- and endoglucanase activities during the fermentation period in submerged cultures. The enzyme production was at the maximum level at $2 \%$ using MCC or CMC and at $4 \%$ concentrations of bean waste biomass (Fig. 4). However, the enzyme activity on bean waste biomass was lower than that produced in MCC or CMC at all substrate concentrations ranged from 1 to $5 \%$. The results indicated that $\mathrm{MCC}$ or $\mathrm{CMC}$ easily produced carbon in enzyme induction. From the current study, $C$. affinis was recorded as plant pathogen; previously Lozovaya et al. (2007) reported that phytopathogenic fungi are able to produce laccase and lignin peroxidase required for lignin degradation in soybean. According to Male (1981), bean biomass was used as a cheap compost for mushroom cultivation and hydrolytic enzymes production (Male 1981). Several studies have shown that Curvularia spp. (Banerjee and Chakrabarti 1992; Okunowo et al. 2010) can produce cellulase, $\beta$-glucosidase, and xylanase enzymes in submerged cultures of lignocellulosic materials. Neoh et al. (2015) explored the capability of C. clavata to produce lignocellulolytic enzymes, such as carboxymethylcellulase, xylanase, manganese peroxidase, laccase, and lignin peroxidase from agro-industrial residues in the palm oil industry. With using bean waste, the enzymes activity was less than using MCC or CMC, which may be due to existence of inhibitors. This result is supported by the findings of Gbekeloluwa and MooYoung (1991), who reported the inhibitory effects of accumulated cellobiose and cellodextrin with low degree of polymerization. Zhang et al. (2013) found that the activity of Bursaphelenchus xylophilus endoglucanase towards MCC and filter paper was less than towards oat gum.

\section{Optimization of exo- and endoglucanase production}

The current study focused on the optimization of enzyme production at different incubation periods in consideration of the myriad and continued demand for 


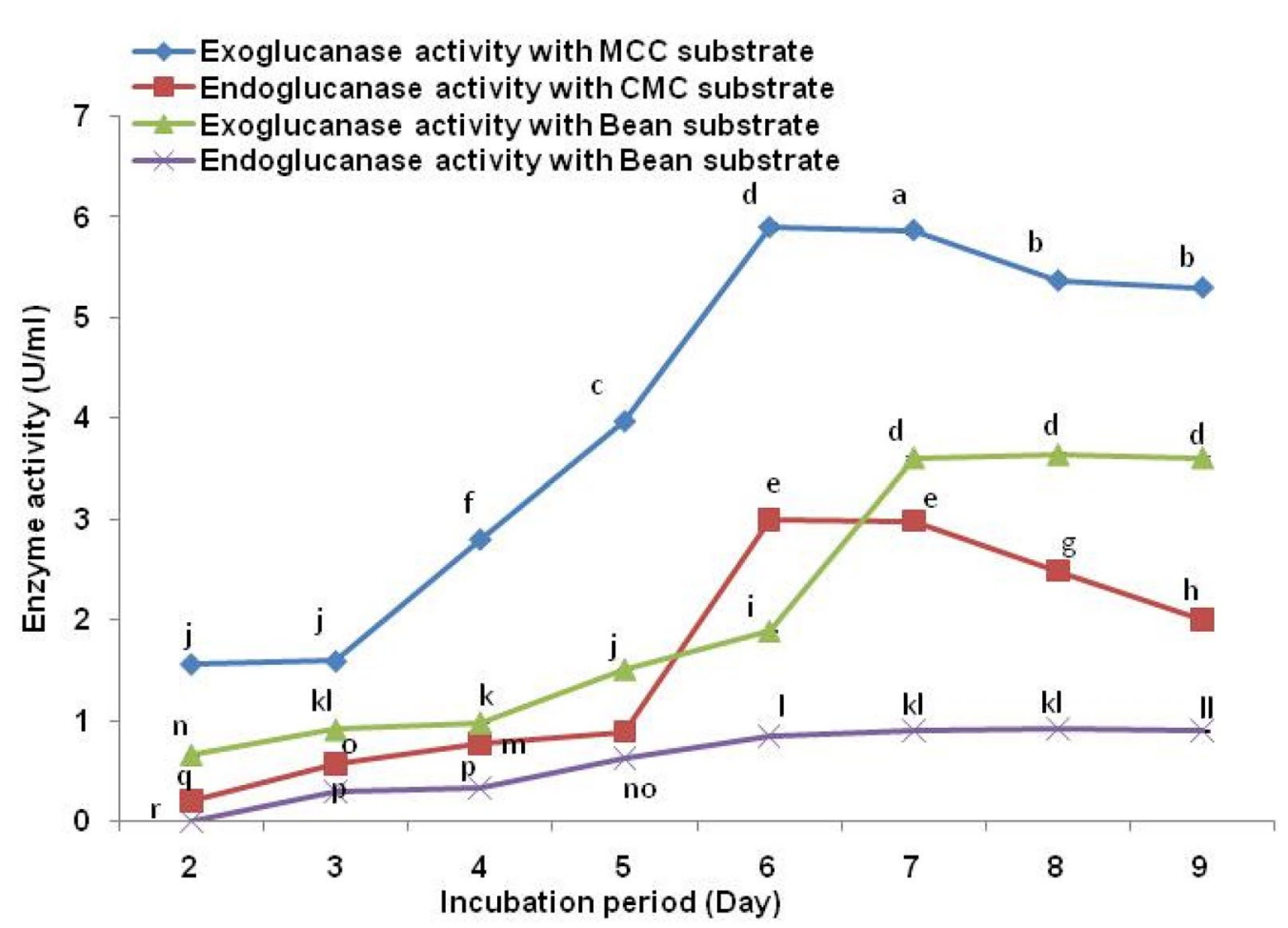

Fig. 5 Effect of different incubation periods on exoglucanase and endoglucanase activities using MCC, CMC and bean substrates

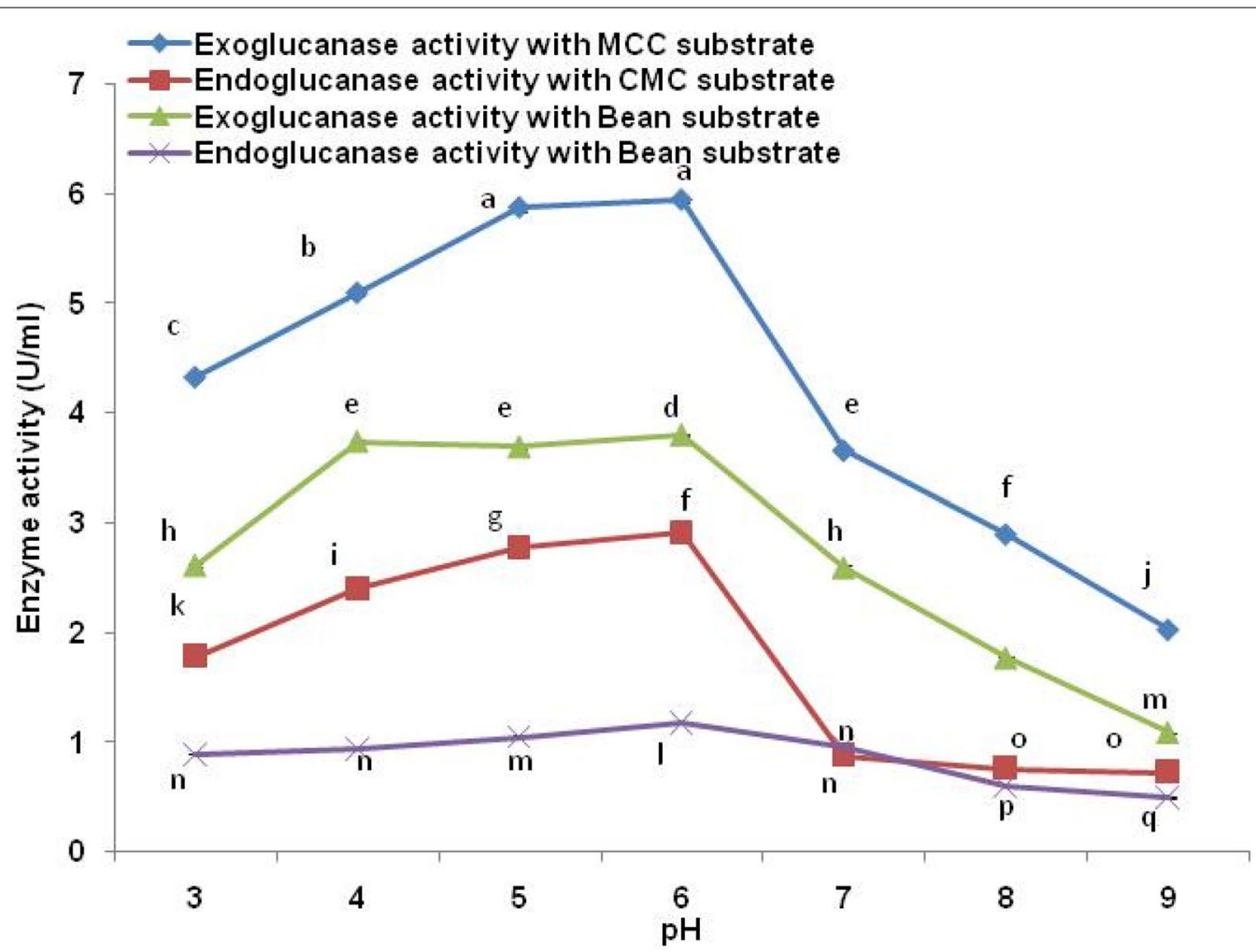

Fig. 6 Effect of different pH on exoglucanase and endoglucanase activities using MCC, CMC and bean substrates 
biotechnological and industrial applications of enzymes (Fig. 5). The optimum incubation periods were identified to be 6 and 8 days for enzyme activity $(5.90$ and $3.64 \mathrm{U} / \mathrm{g}$ of exoglucanase; 2.99 and $0.92 \mathrm{U} / \mathrm{g}$ of endoglucanase) using MCC or CMC as substrates and bean waste biomass, respectively. The MCC and CMC both induced enzyme activity with 6 days of incubation, implying that they are good carbon sources for enzyme induction. However, they may be uneconomical at a large scale. The available agricultural lignocellulosic waste of bean used in this study also induced a favorable amount of enzymes using C. affinis after 8 days. Endoglucanase activity was undetectable at 2 days of incubation, whereas exoglucanase activity was detected using bean waste. This result indicated that exoglucanase was synthesized and excreted earlier than other enzymes, as reported by Li et al. (2013). El-Said et al. (2014) recorded the highest production of exo- and endo- $\beta-1,4$-glucanases by phytopathogenic fungi including Alternaria citri, A. alternata and A. citri and Cochliobolus spicifer isolated from broad bean diseased leaves after 6 and 8 days of incubation period, respectively.
Exoglucanase by C. affinis was also analyzed in the current study to investigate the effect of $\mathrm{pH}$ on the activities of endoglucanase (Fig. 6). Exo- and endoglucanase production showed similar profiles, with maximum activity in cultures at $\mathrm{pH} 5-6$ using MCC or CMC or bean waste. This result was similar to the results of Prasetyo et al. (2010), who studied the cellulase production in $\mathrm{pH}$ controlled cultures. Exo- and endoglucanase production showed maximum activities in cultures at $\mathrm{pH}$ 5.5-6.0. In the current study, acidic $\mathrm{pH}$ (3 and 4) was more effective than alkaline $\mathrm{pH}(7$ and 8$)$ in enzyme production. This result is in agreement with the work of Ali et al. (1991), who reported those $\mathrm{pH}$ levels of 3 and 4 lead to high yields of cellulase enzyme. In other studies, the highest ligninolytic enzyme production has been reported under optimal conditions of pH 5.5 to 6.0 (Rosales et al. 2007; Patrick et al. 2011). Also, El-Said et al. (2014) observed that maximum production of exo- and endo- $\beta-1,4$ glucanases was at $\mathrm{pH} 6$.

Surfactants, especially Tween-80, can increase the bioavailability of less soluble substrates for the fungi and stimulate growth of the fungal spores as well as hydrolytic enzymes (Zheng and Obbard 2001); therefore in

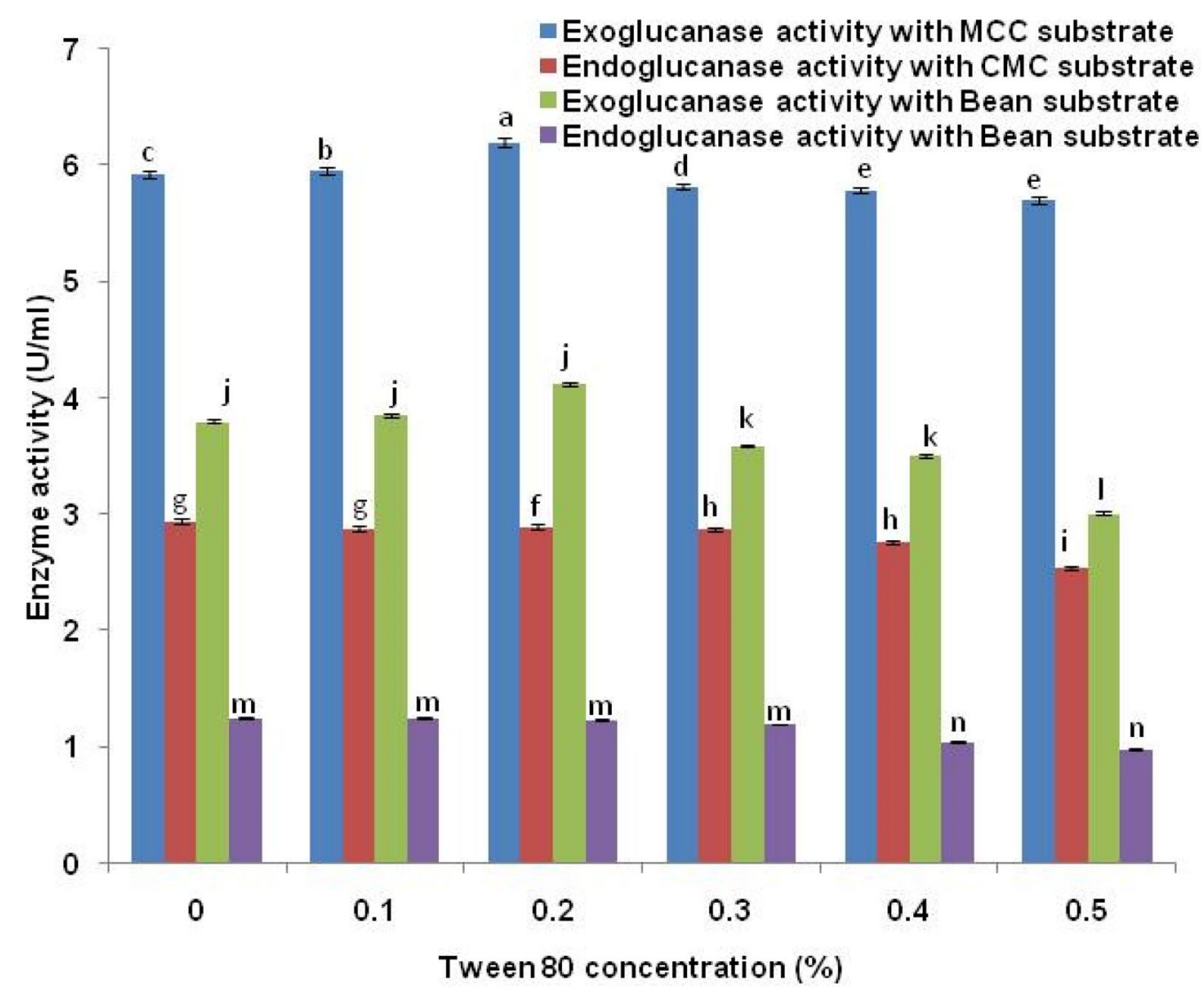

Fig. 7 Effect of different concentrations of Tween 80 on exoglucanase and endoglucanase activities using MCC, CMC and bean substrates 


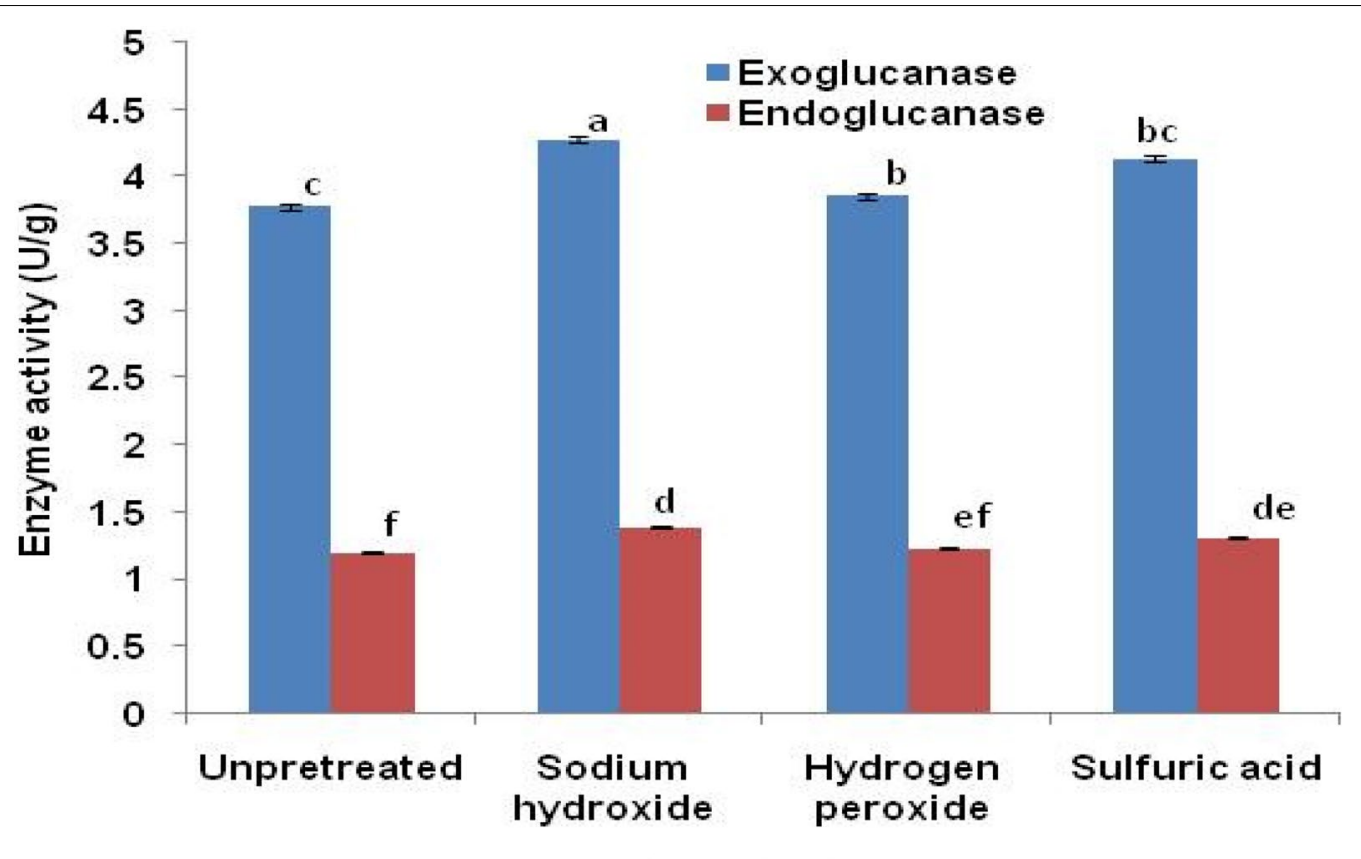

Treatments

Fig. 8 Effect of pretreatments on exoglucanase and endoglucanase activities using bean substrates

the current study, addition of $0.20 \%$ Tween 80 stimulates the activity of exoglucanase and then decreased with increasing Tween 80 concentration (Fig. 7). The exoglucanase activity gradually increased from $5.92 \mathrm{U} / \mathrm{g}$ at $0.0 \%$ to $6.20 \mathrm{U} / \mathrm{g}$ with $0.20 \%$ of Tween 80 and then decreased to $5.70 \mathrm{U} / \mathrm{g}$ at $0.50 \%$ Tween 80 using the MCC substrate. The activity gradually increased from $3.80 \mathrm{U} / \mathrm{g}$ at $0.0 \%$ to $4.12 \mathrm{U} / \mathrm{g}$ at $0.20 \%$ and then decreased to $3.01 \mathrm{U} / \mathrm{g}$ at $0.50 \%$ Tween 80 using bean waste substrate. On the contrary, the endoglucanase activity was negatively influenced by Tween 80 . Although the mechanism by which the surfactants enhance extracellular enzyme production in filamentous fungi has not been elucidated (Wang et al. 2006), the obtained results may be due to the surfactant affecting the permeability of fungal cell membrane, thus contributing to enzyme secretion into the media and lowering the concentration of intracellular enzymes. Our results agree with those reported by Guoweia et al. (2011).

\section{Effect of pretreatments of bean substrates for exo- and endoglucanase production}

Bean biomass pretreated with any treatments yielded higher enzyme production than that of unpretreated substrates (Fig. 8). Sun and Cheng (2002) stated that alkaline pretreatment increased internal surface area and fiber distension in agricultural biomass; therefore, the released cellulose and hemicellulose induce $C$. affinis growth and its hydrolytic enzymes. The results indicated that alkaline-pretreated biomass showed the highest enzyme production compared with acid-treated residues, followed by $\mathrm{H}_{2} \mathrm{O}_{2}$-treated ones. The findings in this study agree with those reported (Zhang et al. 2012; Salihu et al. 2015) using acid- and alkali-treated agricultural wastes. Enzymes yielded from biomass pretreated with $\mathrm{H}_{2} \mathrm{O}_{2}$ showed lower activities than those with alkaline or acid pretreatments, which might be due to the inhibitory effects induced by the hydrolysates from bean biomass.

\section{Conclusion}

Results confirm the suitability of using low-cost and abundant bean waste as solid substrate for exo- and endoglucanase production. C. affinis is a relatively good producer of exo- and endoglucanase under optimum conditions of $\mathrm{pH}$, incubation period, substrate concentration, and surfactant.

\section{Acknowledgements}

The authors are thankful to the Faculty of Science, Jazan University.

\section{Authors' contributions}

AMM designed the experiments, wrote the paper, is the corresponding author for journal, analyzed and interpreted the data. AAA contributed to fungal identification, analyzed and interpreted the data, performed the experiments; contributed reagents, materials and analysis tools or data, analyzed and 
interpreted the data; wrote and English edited the paper. All authors read and approved the final manuscript.

\section{Funding}

This research did not receive any specific grant from funding agencies in the public, commercial, or not-for-profit sectors.

\section{Availability of data and materials}

The data set (table and graphs) supporting this article's conclusion is available.

\section{Ethics approval and consent to participate}

Not applicable.

\section{Consent for publication}

Not applicable.

\section{Competing interests}

The authors declare that they have no competing interests.

Received: 30 October 2019 Accepted: 1 February 2020

Published online: 08 February 2020

\section{References}

Abdel Ghany TM, Masmali IA (2016) Fungal biodegradation of organophosphorus insecticides and their impact on soil microbial population. J Plant Pathol Microbiol 7(5):1000349

Abdel Ghany TM, Elhussieny NI, Shater AR (2014) Biobeneficial spectrum of halophyte plant Avicennia marina as a second generation of bioethanol production. J Biol Chem Res 31(2):869-881

Abdel-Ghan TM (2013) Stachybotrys chartarum: a novel biological agent for the extracellular synthesis of silver nanoparticles and their antimicrobial activity. Indonesian J Biotechnol 18(2):75-82

Abdel-Ghany TM, Bakri MM (2019) Effectiveness of a biological agent (Trichoderma harzianum and its culture filtrate) and a fungicide (methyl benzimacold-2-ylcarbamate) on the tomato rotting activity (growth, celluloytic, and pectinolytic activities) of Alternaria solani. Bioresources 14(1):1591-1602

Abdelghany TM, Al-Rajhi AM, Al Abboud MA, Alawlaqi MM, Magdah AG, Helmy EA, Mabrouk AS (2018) Recent advances in green synthesis of silver nanoparticles and their applications: about future directions. A review. Bionanoscience 8(1):5-16

Abdel-Ghany TM, Ganash M, Bakri MM, Al-Rajhi AM (2018) Molecular characterization of Trichoderma asperellum and lignocellulolytic activity on barley straw treated with silver nanoparticles. BioResources 13(1):1729-1744

Abdel-Ghany TM, Alawlaqi MM, Shater AR, Al Abboud MA (2019) Congo red biosorption with live and dead biomass of thermophilic Aspergillus fumigates. Egypt J Exp Biol 15(1):1-6

Abdel-Razek AS, Abdel-Ghany TM, Mahmoud SA, ElSheikh HH, Mahmoud MS (2009) The use of free and immobilized Cunninghamella elegans for removing cobalt ions from aqueous waste solutions. World J Microbiol Biotechnol 25:2137-21450

Acharya PB, Acharya DK, Modi HA (2008) Optimization for cellulase production by Aspergillus niger using saw dust as substrate. Afr J Biotechnol 7(22):4147-4152

Ali S, Sayed A, Sarker RT, Alau R (1991) factors affecting cellulase production by Aspergillus niger and Aspergillus terreus, using water hyacinth. World J Microbiol Biotech 7:62-66

Anasontzis GE, Thanh N, Thi D, Hang M, Thu H, Tat D, Olsson L (2017) Rice straw hydrolysis using secretomes from novel fungal isolates from Vietnam. Biomass Bioenerg 99:11-20

Banerjee UC, Chakrabarti S (1992) Production and properties of carboxymethylcellulase 3 (endo-1,4-b-glucanase) from Curvularia lunata. World J Microbiol Biotech 8(4):423-424

Béguin P (1990) Molecular biology of cellulose degradation. Annu Rev Microbiol 44:219-248

Bhat MK (2000) Cellulases and related enzymes in biotechnology. Biotechnol Adv 18:355-383

Chen L, Zou G, Wang J, Wang J, Liu R, Jiang Y, Zhao G, Zhou Z (2016) Characterization of the $\mathrm{Ca} 2+$-responsive signaling pathway in regulating the expression and secretion of cellulases in Trichoderma reesei Rut-C30. Mol Microbiol 2016(100):560-575

Chen Y, Shen Y, Wang W, Wei D (2018) $\mathrm{Mn}^{2+}$ modulates the expression of cellulase genes in Trichoderma reesei Rut-C30 via calcium signaling. Biotechnol Biofuels. https://doi.org/10.1186/s13068-018-1055-6

de Moraes Rocha GJ, Nascimento VM, da Silva VF (2014) Enzymatic bioremediation of effluent from sugarcane bagasse soda delignification process. Waste Biomass Valor 5(6):919-929

Delgado-Serrano L, Restrepo S, Bustos JR, Zambrano MM, Anzola JM (2016) Mycofier: a new machine learning-based classifier for fungal ITS sequences. BMC Res Notes 9:402

El-Said AHM, Saleem A, Maghraby TA, Hussein MA (2014) Cellulase activity of some phytopathogenic fungi isolated from diseased leaves of broad bean. Int J Curr Microbiol App Sci 3(2):883-900

Gbekeloluwa BO, Moo-young M (1991) Production and properties of $\beta$-glucosidase by Neurospora sitophila. World J Microb Biotechnol 7:4-11

Gharpuray MM, Lee YH, Fan LT (1983) Structural modification of lignocellulosic by treatment to enhance enzymatic hydrolysis. Biotechnology 25:157-170

Guoweia S, Man H, Shikai W, He C (2011) Effect of some factors on production of cellulase by Trichoderma reesei HY07. Proc Environ Sci 8:357-361

Henrissat B, Driguez H, Viet C, Schülein M (1985) Synergism of cellulases from Trichoderma reesei in the degradation of cellulose. Biotechnology 3:722-726

Huang JB, Zheng L, Hsiang T (2004) First report of leaf spot caused by Curvularia affinis on Festuca arundinacea in Hubei China. Plant Dis 88:1048

Iftikhar S, Amir S, Anjum M, Shazia I, Iftikhar A (2003) Fungi associated with rice-wheat cropping system in relation to zero and conventional tillage technologies. J Biol Sci 3:1076-1083

Jecu L (2000) Solid-state fermentation of agricultural wastes for endoglucanase production. Ind Crop Prod 11:1-5

Kamaluddeen Simon S, Lal AA (2013) A new blight disease of rice caused by Curvularia lunata from Uttar Pradesh. Int J Agric Sci Res 5:13-16

Keegstra K (2010) Plant cell walls. Plant Physiol 154:483-486

Kim SJ, Lee CM, Han BR, Kim MY, Yeo YS, Yoon SH, Koo BS, Jun HK (2008) Characterization of a gene encoding cellulase from uncultured soil bacteria. FEMS Microbiol Lett 282:44-51

Krishnan HK, Muni NM, Sahruna NS, Nadarajah K (2014) Severity of rice disease caused by Curvularia sp in Malaysia. J Adv Biol 4(1):266-275

Li G, Zhenhua Y, Zhang R, Zhang D, Shulin C, Ma L (2013) Effect of pH on cellulase production and morphology of Trichoderma reesei and the application in cellulosic material hydrolysis. J Biotechnol 168:470-477

Lin J, Pillay B, Singh S (1999) Purification and biochemical characteristics of beta-D-glucosidase from a thermophilic fungus, Thermomyces lanuginosus-SSBP. Biotechnol Appl Biochem 30(Pt 1):81-87

Lozovaya WV, Lygin AV, Zernova OV, Ulanov AV, Li S, Hartman GL, Widholm JM (2007) Modification of phenolic metabolism in soybean hairy roots through down regulation of chalcone synthase or isoflavone synthase. Planta 225:665-679

Madhusree H, Surekha K (2017) Isolation of Curvularia affinis causing rice leaf spot from West Bengal rice field and optimization of culture conditions. Int Adv Res J Sci Eng Technol 4(8):64-68

Madrid H, da Cunda KC, Gené J, Dijksterhuis J, Cano J, Sutton DA, Guarro J, Crous PW (2014) Novel Curvularia species from clinical specimens. Persoonia 33:48-60

Makky EA, Abdel Ghany TM (2009) Cellulases applications in biological deinking of old newspaper wastes as carbon source produced by Bacillus subtilis. Egypt J Exp Biol 5:85-89

Male RT (1981) The use of spent mushroom compost in vegetable production. Mushroom Sci 11(1):111-121

Mandels M, Reese ET (1957) Induction of cellulase in Trichoderma viride as influenced by carbon sources and metals. J Bacteriol 73:269-278

Marin-Felix J, Groenewald JZ, Cai L, Chen Q, Marincowitz S et al (2017) Genera of phytopathogenic fungi: GOPHY 1. Stud Mycol 86:99-216

Mohajershojaei K, Khosravi A, Mahmoodi NM (2013) Decolorization of dyes using laccase enzyme from single and binary systems. Desalin Water Treat 52(10-12):1895-1902

Moreira FG, Simone R, Costa MAF, Marques de Souza CG, Peralta RM (2005) Production of hydrolytic enzymes by the plant pathogenic fungus Myrothecium verrucaria in submerged cultures. Braz J Microbiol 36:7-11 
Neoh CH, Lam CY, Adibah Y, Ismail W, Zaharah I (2015) Utilization of agroindustrial residues from palm oil industry for production of lignocellulolytic enzymes by Curvularia clavata. Waste Biomass Valor 6:385-390

Okunowo OW, Gbenle GO, Osuntoki AA, Adedotun AA, Sikiru AO (2010) Production of cellulolytic and xylanolytic enzymes by a phytopathogenic Myrothecium roridum and some avirulent fungal isolates from water hyacinth. Afr J Biotech 9(7):1074-1078

Orzua MC, Mussatto SI, Contreras-Esquivel JC, Rodriguez R, De la Garza H, Teixeira JA, Aguilar CN (2009) Exploitation of agro industrial wastes as immobilization carrier for solid-state fermentation. Ind Crops Prod 30:24-27

Patrick F, Mtui G, Mshandete AM, Kivaisi A (2011) Optimization of laccase and manganese peroxidase production in submerged culture of Pleurotus sajor-caju. Afr J Biotechnol 10(50):10166-10177

Prasetyo J, Sumita S, Okuda N, Park EY (2010) Response of cellulase activity in $\mathrm{pH}$-controlled cultures of the filamentous fungus Acremonium cellulolyticus. Appl Biochem Biotechnol 162:52-61

Rodríguez-Couto S (2008) Exploitation of biological wastes for the production of value-added products under solid-state fermentation conditions. Biotechnol J 3:859-870

Romanelli AM, Sutton DA, Thompson EH, Rinaldi MG, Wickes BL (2010) "Sequence-based identification of filamentous basidiomycetous fungi from clinical specimens: a cautionary note. J Clin Microbiol 48(3):741-752

Rosales E, Couto SR, Sanromán MA (2007) Increased laccase production by Trametes hirsuta grown on ground orange peelings. Enzyme Microbial Technol 40(5):1286-1290

Saha BC (2004) Production, purification and properties of endoglucanase from a newly isolated strain of Mucor circinelloides. Process Biochem 39:1871-1876

Salihu A, Olagunju A, Abdullahi BS, Md Zahangir A (2015) Agricultural residues for cellulolytic enzyme production by Aspergillus niger: effects of pretreatment. Biotech 5(6):1101-1106

Sambrook J, Maccallum P, Russel D (2001) Molecular cloning: a laboratory manual, 3rd edn. Cold Springs Harbour Press, New York, p 2344

Sharma P, Singh N, Verma OP (2012) First report of Curvularia leaf spot, caused by Curvularia affinis on Dalbergia sissoo. For Pathol 42(3):265-266

Shirsath LP, Patil SP, Patil UK (2018) Incidence of leaf spot disease on cotton caused by Curvularia verruculosa and role of its hydrolytic enzymes in pathogenesis. Physiol Mol Biol Plants 24:711-714

Singh A, Bishnoi NR (2013) Comparative study of various pretreatment techniques for ethanol production from water hyacinth. Ind Crops Prod 44:283-289

Smith JD, Jackson N, Woolhouse AR (1989) Fungal diseases of amenity turf grasses. E \& F.N. Spon, New York
Solehudin D, Suswanto I, Supriyanto (2012) Status penyakit bercak coklat pada pembibitan kelapa sawt di Kabupaten Sanggau. J Perkebunan Lahan Trop 2:1-6

Somerville C (2006) Cellulose synthesis in higher plants. Ann Rev Cell Dev Biol 22:53-78

Sun Y, Cheng J (2002) Hydrolysis of lignocellulosic materials for ethanol production: a review. Bioresour Technol 83:1-11

Tamura K, Stecher G, Peterson D, Filipski A, Kumar S (2013) MEGA6: molecular evolutionary genetics analysis version 6.0. Mol Biol Evol 30(12):2725-2729

Tunali S, Ozcan A, Kaynak Z, Ozcan AS, Akar T (2007) Utilization of the Phaseolus vulgaris $\mathrm{L}$. Waste biomass for decolorization of the textile dye Acid Red 57: determination of equilibrium, kinetic and thermodynamic parameters. J Environ Sci 42(5):591-600

Verma N, Mukesh CB, Vivek K (2011) Pea peel waste: a lignocellulosic waste and its utility in cellulase production by Trichoderma reesei under solid state cultivation. BioResources 6(2):1505-1519

Wang XJ, Bai JG, Liang YX (2006) Optimization of multienzyme production by two mixed strains in solid-state fermentation. Appl Microbiol Biotechnol 73(2006):533-540

Weng Q, Wang Q, He Y, Liu M, Yu D (1997) The occurrence of turf diseases in Fujian province. Acta Pratacult Transact 6:70-73

Wilson J.P. 2000.Pearl millet diseases. A compilation of Information on the Known Pathogens of Pearl Millet Pennisetum glaucum(L.) R. Br. United States Department of Agriculture, Agricultural Research Service, Agriculture Handbook Number 716

Wyman CE (1994) Ethanol from lignocellulosic biomass: technology, economics and opportunities. Bioresour Technol 50:3-16

Zaldivar M, Velasquez JC, Contreras I, Perez LM (2001) Trichoderma aureoviride 7-121, a mutant with enhanced production of lytic enzymes; its potential use in waste cellulose degradation and/or biocontrol. Elect J Biotechnol 4(3):13-14

Zhang L, Liu Y, Niu X, Liu Y, Liao W (2012) Effects of acid and alkali treated lignocellulosic materials on cellulase/xylanase production by Trichoderma reesei Rut C-30 and corresponding enzymatic hydrolysis. Biomass Bioenerg 37:16-24

Zhang L, Fan Y, Zheng H, Du F, Zhang K-q, Huang X, Wang L, Man Zhang M, Niu Q (2013) Isolation and characterization of a novel endoglucanase from a Bursaphelenchus xylophilus metagenomic library. PLoS ONE 8(12):e82437. https://doi.org/10.1371/journal.pone.0082437

Zheng ZM, Obbard JP (2001) Effect of nonionic surfactants on elimination of polycyclic aromatic hydrocarbons (PAHs) in soil slurry by Phanerochaete chrysosporium. J Chem Technol Biotechnol 2001(76):423-429

\section{Publisher's Note}

Springer Nature remains neutral with regard to jurisdictional claims in published maps and institutional affiliations.

\section{Submit your manuscript to a SpringerOpen ${ }^{\circ}$ journal and benefit from:}

- Convenient online submission

- Rigorous peer review

- Open access: articles freely available online

- High visibility within the field

Retaining the copyright to your article

Submit your next manuscript at springeropen.com 